International Journal of Agriculture and Environmental Research

ISSN: 2455-6939

Volume: 07, Issue: 05 "September-October 2021"

\title{
REGENERATION OF COFFEE FARMERS: A CASE IN MALANG REGENCY, EAST JAVA PROVINCE, INDONESIA
}

\author{
*Jabal Tarik Ibrahim, Wisnu Elman Bunaya, Fithri Mufriantie \\ Agribusiness Department, Faculty of Agriculture and Animal Science, \\ University of Muhammadiyah Malang, Malang 65144, East Java, Indonesia \\ *Corresponding author
}

DOI: https://doi.org/10.51193/IJAER.2021.7501

Received: 03 Sep 2021 / Accepted: 10 Sep 2021/ Published: 28 Sep 2021

\begin{abstract}
The low interest of today's generation in agriculture has resulted in a small number of young farmers in Indonesia. There is a need of change between the coffee farmers who are no longer productive and younger coffee farmers through the process of coffee farmer regeneration. This study aims to determine the state of regeneration of coffee farmers, the impact of local instructor, education level, land ownership, and income from other sectors on the regeneration of coffee farmers in Karangploso District. This research used descriptive research with qualitative method and phenomenological approach. The data were analyzed with analysis techniques and data representation from Cresswell. The result shows that the regeneration of coffee farmers are taking places in only 4 villages and has been occurring for three generations from 1990, the role of local agricultural instructors are still limited, the education level of coffee farmers range from elementary to junior high school level, some farmers who do not own land cooperate with Perhutani, and coffee farming is not the main source of income for coffee farmers. It is important to continue the regeneration of coffee farmers in Karangploso District, considering that Karangploso District is a coffee-producing area.
\end{abstract}

Keywords: Coffee, Farmer, Karangploso, Regeneration

\section{INTRODUCTION}

Indonesia is a country with abundant agricultural products. Agricultural sector is one of the sectors that have contributed economically to Indonesia, where in developing countries the agricultural sector is the sector with the highest labor absorption (Ibrahim \& Mazwan, 2021). 
International Journal of Agriculture and Environmental Research

ISSN: 2455-6939

Volume: 07, Issue: 05 "September-October 2021"

However, in recent years the decline in the number of young people who want to follow their parents' jobs in the agricultural sector has caused a crisis of younger generation former, beside that most of the older people in rural areas do not want their children to work in agricultural sector (Ibrahim, JT., Mufriantie, F. 2021). The conversion of land functions which continues to occur also cause the amount of agricultural land to shrink. The major challenge face by people involve in the agricultural sector is related to the regeneration of farmers. The low interest of the younger generation in agriculture has an impact on the number of farmers which continue to decline and the workforce in the agricultural sector is decreasing (Wardani \& Anwarudin, 2018). There are many factors that affect the regeneration of farmers; education level, income, the size of area they owned, agricultural commodities, and parental support which significantly affect one's perception on employment in the agricultural sector (Rahmawati E. T., et al. 2021).

The proportion of farmer households (RTP) to the total number of households tends to decline over the last 10 years. The decline in agricultural households shows that there is a proportional decrease in the number of farmers and farm laborers (Ibrahim J.T., et al. 2021). Families of these farmers reckon that ideally, regeneration process of farmers happens through a diversion scheme of farming activities from parents to children. The succession of agricultural transfers is affected by salary in agricultural sector, education level, age, income from agricultural activities, and experience (Mishra et al., 2010). Most of the time, the government failed to outline problems that the farmers face at the upstream to downstream level which then influence the regeneration of farmers. Karangploso district is one of the areas that produce coffee as it commodity in Malang Regency. Coffee in Karangploso district is a potential commodity, which even included in the top 10 of highest productive plant commodities in Malang Regency. Majority of coffee plantations in Karangploso are managed by the local community. Common problems that often occur among coffee farmers are the low technological capabilities, the limited number expert, and scarcity of land. Furthermore, some of these farmers have to use Perhutani's land to plant their coffee with agreement from both parties which caused by the land problems that they have. This research was conducted to discover the regeneration process of coffee farmers and to determine the effect of local agricultural instructor, farmers' education level, land ownership and income from other sectors on the regeneration of coffee farmers in Karangploso District.

\section{METHODS}

Type of the research is descriptive research. The method used in this study is a qualitative research method using a phenomenological approach. The type of data used is primary data and secondary data. The research was conducted in Karangploso District, Malang Regency, and East Java Province. The population in this study were coffee farmers in Karangploso District, Malang Regency. Informants in this study are people who are considered to understand and understand 
the problems being studied for a long period of time, namely the regeneration of coffee farmers in Karangploso District, have regenerated and can assist researchers in obtaining data in the field. Informants were taken using the purposive sampling technique. The purposive sampling technique is a technique of taking informants or sources with the aim of obtaining the necessary information, researchers take samples based on specific characteristics so that the population can represent and match the research design (Nasution, 2011). The researcher is based on the criteria of informants, selecting 36 coffee farmers as informants. The analytical technique used is the analysis technique and data representation according to Creswell in Hamyana (2017) for phenomenological research as presented in Table 1.

Table 1: Phenomenological data analysis and representation techniques

\begin{tabular}{|c|c|c|}
\hline No. & $\begin{array}{l}\text { Data Analysis And } \\
\text { Representation }\end{array}$ & Phenomenological Research \\
\hline 1 & Data processing & Processing and organizing data \\
\hline 2 & Read and remember data & Reading text, making notes, and creating initial codes \\
\hline 3 & Drawing data & Describing the meaning of events for researchers \\
\hline 4 & Classifying data & $\begin{array}{l}\text { a. Find meaningful questions and make a list } \\
\text { b. Grouping the same questions into certain meaning } \\
\text { units. }\end{array}$ \\
\hline 5 & Data interpretation & $\begin{array}{l}\text { a. Building a textural description (what happened) } \\
\text { b. Build a structural description (how an event was } \\
\text { experienced) } \\
\text { c. Build an overall description of the event (the essence } \\
\text { of the event) }\end{array}$ \\
\hline 6 & $\begin{array}{l}\text { Data visualization } \\
\text { presentation }\end{array}$ & $\begin{array}{l}\text { The narrative of the essence of the event is equipped with } \\
\text { a table of questions of meaning units }\end{array}$ \\
\hline
\end{tabular}

\section{RESULTS AND DISCUSSION}

\section{Short profile of the informant}

This study produced several findings related to the state of regeneration of coffee farmers in Karangploso District, in describing the results of the study, it was started by presenting brief profiles of several informants.

\section{Infromant $\mathrm{NH}$}

$\mathrm{NH}$ is a 37-year-old resident of Bocek Village, Karangploso District. NH's education level is Madrasah Tsanawiyah or equivalent to junior high school (JHS). For approximately 21 years, he has been a coffee farmer in Karangploso District, namely from 1999. The coffee plantation area 
International Journal of Agriculture and Environmental Research

ISSN: 2455-6939

Volume: 07, Issue: 05 "September-October 2021"

owned by NH is around $2000 \mathrm{~m}^{2}$ with the type of coffee being cultivated, namely Robusta coffee. $\mathrm{NH}$ is the third generation successor to the coffee plantation that is owned now, which was originally owned by my grandfather. The reason why $\mathrm{NH}$ continues its coffee farming activities is that $\mathrm{NH}$ really likes coffee plants and $\mathrm{NH}$ considers that coffee farming is a farming business that is easy to maintain and does not require a lot of money.

\section{Informant MS}

MS is a 42-year-old resident of Ngenep Village, Karangploso District. NH's education level is Elementary School. He has been a coffee farmer for approximately 22 years in Karangploso District, namely from 1998. The area of the coffee plantation owned by MS is approximately $1000 \mathrm{~m}^{2}$ with the type of coffee being cultivated, namely Robusta coffee. MS is the second generation who continues the coffee farming from his parents. The reason why MS continued his coffee farming activities from his parents was that the prices were still good for coffee commodities and also because he didn't want to dismantle and replace the commodities he farmed.

\section{Infromant PJ}

PJ is a 38-year-old resident of Donowarih Village, Karangploso District. PJ's education level is elementary school (ES). He has been a coffee farmer in Karangploso Subdistrict for about 17 years, from 2000. The area of the coffee plantation owned by PJ is about $2000 \mathrm{~m}^{2}$ with the type of coffee being cultivated, namely Arabica. The majority of coffee farmers in Donowarih Village plant Arabica coffee because the height is high enough to grow Robusta coffee. PJ is the third generation who continues the coffee farming activities that were started by his parents. The reason $\mathrm{PJ}$ continues his coffee farming activities is that it has been passed down from generation to generation, besides that coffee plants are plants that are easy to care for.

\section{Informant GT}

GT is a 26-year-old resident of Tawangargo Village, Karangploso District. GT's education level is an elementary school (ES). He has been a coffee farmer in Karangploso District for about 8 years, from 2012. The coffee plantation area controlled by GT is around $1000 \mathrm{~m}^{2}$, with the type of coffee being cultivated, namely Arabica. Farmers in Donowarih Village with Tawangargo Village indeed mostly grow Arabica coffee because the height is high enough to grow Arabica coffee, besides that the selling price is more expensive than Robusta being one of the reasons. GT is the second generation to continue the coffee farming activities that were previously owned by GT's parents. The reason why GT wants to continue its coffee farming activities is that it has been hereditary, besides that the average coffee plantation in Tawangargo Village is on forest land so it is an appeal from Perhutani to grow coffee. 


\section{The state of regeneration of coffee farmers in Karangploso district}

The transfer of knowledge and coffee farming activities or commonly called farmer regeneration has been going on for three generations in Karangploso District, as stated by several informants, including $\mathrm{NH}$ "In the beginning, the coffee plantation that I have now started with my grandfather, then passed on by my father, then it goes down. to me". MS "In the village, when you are old enough, you really help your father in the land, so it's like hereditary agriculture in the village, including coffee plantations". PJ "The coffee plantation that I own, Niku, has continued from my father, which was originally started by my grandfather". Regeneration of farmers or transfer of coffee farming in Karangploso sub-district occurs in the family environment which is passed down from generation to generation to younger generations.

Anwarudin et al., (2020), revealed that farmer regeneration can occur in a family environment where the management of farming is inherited from parents to their children or non-family in the form of inheritance of farming businesses to people who are not family or immigrants. Based on information from several informants, coffee cultivation activities in Karangploso Regency have existed since the 90 s and have been going on for three generations until now.

\section{Level of education}

The level of education of coffee farmers in Karangploso District is only up to elementary school or old informants call it SR or people's school. The highest education level of coffee farmers in Karangploso District is only up to junior high school or its equivalent. The education level of the informants can be seen in the following table:

\section{Table 2: Level of Education of Informants}

\begin{tabular}{|c|c|c|}
\hline Name & Village & Level of Education \\
\hline UD & Bocek & JHS \\
\hline $\mathrm{NH}$ & Bocek & JHS \\
\hline SH & Bocek & PS \\
\hline TD & Bocek & PS \\
\hline KL & Bocek & JHS \\
\hline SNO & Bocek & PS \\
\hline SD & Bocek & PS \\
\hline TD & Bocek & PS \\
\hline $\mathrm{T} \mathrm{S}$ & Bocek & PS \\
\hline TR & Donowarih & JHS \\
\hline SN & Donowarih & PS \\
\hline SW & Donowarih & PS \\
\hline ST & Donowarih & PS \\
\hline SP & Donowarih & PS \\
\hline
\end{tabular}




\begin{tabular}{lcc} 
PJ & Donowarih & PS \\
SA & Donowarih & PS \\
SY & Donowarih & PS \\
SJ & Donowarih & JHS \\
SS & Tawangargo & PS \\
GT & Tawangargo & PS \\
SM & Tawangargo & PS \\
SK & Tawangargo & PS \\
WH & Tawangargo & PS \\
E A & Tawangargo & PS \\
SI & Tawangargo & PS \\
KM & Tawangargo & PS \\
WS & Tawangargo & JHS \\
SU & Ngenep & PS \\
SO & Ngenep & JHS \\
S & Ngenep & PS \\
MS & Ngenep & PS \\
SNR & Ngenep & PS \\
TM & Ngenep & JHS \\
TH & Ngenep & PS \\
DR & Ngenep & PS \\
AT & Ngenep & PS \\
\hline
\end{tabular}

Source: Research primary data, processed in 2021

PS : Primarry school

JHS : Junior High School

Based on the table above, it can be seen that the number of informants with a junior high school education level or the equivalent is only 8 people, while the remaining 28 people are only elementary school or equivalent. Coffee farmers in Karangploso sub-district have the opinion that school is not a basic need in their environment, as stated by several informants, including MS "In ancient times it was not easy to go to school. the school is there but can't afford it, besides that it's more important to think about the family economy ".

$\mathrm{NH}$ "in the village the education level of farmers who are my age is only up to elementary school, the villagers have a thought that instead of spending money and time on school, it is better to help with farming, so it is more useful".

According to MS and NH's view, economic problems are more important than education issues where when they are old enough, it is better to help parents on the land so that it will be more useful, meaning that the benefits are more visible than having to go to school whose benefits cannot be seen directly. With education, a person will have extensive knowledge, easy to develop ideas, easy to adopt technology and a more dynamic attitude towards new things, especially in the face of more modern changes (Juliansyah \& Riyono, 2018). 
GT "My school education is only up to elementary school, if you really have the intention of becoming a farmer, you don't need a high level of education"

According to the informant, it is not necessary to have high education and degree to become a farmer, as stated by Suharyanto, et all. education which on average does not finish elementary school, it can be understood that work in the agricultural sector today is not a job that requires a special level of expertise/skills.

\section{Types of Coffee Cultivated}

There are only two types of coffee cultivated by coffee farmers in the Karangploso sub-district, namely Arabica and Robusta. There are four types of coffee plants that are cultivated in Indonesia, namely Robusta Coffee, Arabica, Liberika, and Ekselsa. The types of coffee plants that are widely traded in Indonesia and have a fairly high economic value are Robusta and Arabica (Hamzah et al., 2021). The type of coffee grown by coffee farmers in Karangploso District depends on each region due to differences in regional elevation.

Coffee farmers in Bocek and Ngenep villages tend to cultivate robusta coffee because according to some informants the results of cultivating Arabica coffee are not as good as Robusta coffee.

MS "if in this area you do not dare to plant Arabica coffee, you are afraid that the results will not be optimal" .

Coffee farmers in Donowarih and Tawangargo villages are more likely to cultivate Arabica coffee, as said by one of the informants,

GT "the type of coffee grown in the Tawangargo area is Arabica, because the height is quite high for Arabica and the selling price is more expensive".

The types of coffee cultivated by the informants can be seen in the following table:

Table 3: Types of Coffee Cultivated by Informants

\begin{tabular}{llc}
\hline \multicolumn{1}{c}{ Name } & Village & Species of Coffee \\
\hline UD & Bocek & Robusta and arabika \\
N H & Bocek & Robusta \\
SH & Bocek & Robusta \\
TD & Bocek & Robusta \\
KL & Bocek & Robusta \\
SNO & Bocek & Arabica \\
SD & Bocek & Robusta \\
TD & Bocek & Robusta \\
T S & Bocek & Robusta and arabica
\end{tabular}




\begin{tabular}{lcc} 
TR & Donowarih & Robusta \\
SN & Donowarih & Arabica \\
SW & Donowarih & Arabica \\
ST & Donowarih & Arabica \\
SP & Donowarih & Robusta and arabica \\
PJ & Donowarih & Arabica \\
SA & Donowarih & Robusta \\
SY & Donowarih & Robusta \\
SJ & Donowarih & Robusta and arabica \\
SS & Tawangargo & Arabica \\
GT & Tawangargo & Arabica \\
SM & Tawangargo & Arabica \\
SK & Tawangargo & Arabica \\
WH & Tawangargo & Robusta and arabica \\
E A & Tawangargo & Robusta and arabica \\
SI & Tawangargo & Arabica \\
KM & Tawangargo & Robusta and arabica \\
WS & Tawangargo & Arabica \\
SU & Ngenep & Robusta and arabica \\
SO & Ngenep & Robusta \\
S & Ngenep & Robusta \\
MS & Ngenep & Robusta \\
SNR & Ngenep & Robusta \\
TM & Ngenep & Robusta \\
TH & Ngenep & Robusta \\
DR & Ngenep & Robusta \\
AT & Ngenep & Robusta \\
\hline Sour & \\
\hline
\end{tabular}

Source: Research primary data, processed in 2021

The type of coffee cultivated by coffee farmers considers the economic value and ease of cultivation. Coffee farmers in Ngenep Village and Bocek Village choose to plant Robusta coffee because it is easier to care for and less susceptible to disease than Arabica coffee,

NH "I only grow Robusta Java coffee, there is no Arabica coffee because Arabica is more difficult to maintain., so many people here grow Java robusta, arabica is susceptible to pests and diseases,".

Hamzah et al., (2021), said that Arabica coffee cultivation is more susceptible to plant diseases. Therefore, the area of coffee cultivation and the largest coffee production in Indonesia is Robusta Coffee. 
International Journal of Agriculture and Environmental Research

ISSN: 2455-6939

Volume: 07, Issue: 05 "September-October 2021"

The regeneration of coffee farmers in the Karangploso Sub-district is still ongoing, mostly due to passing on from parents, not bothering to dismantle land to replace planted commodities, appeals by forest officials, and considering a good market for coffee.

MS "I want to become a coffee farmer because I passed on from my parents, besides that, I also consider the sales, mas, which are still good",

PJ "I became a farmer because I passed on from my parents, besides that it was also an appeal from forest officials, to grow coffee ",

GT "I became a coffee farmer because there are indeed many pine trees in this area, so the plants that can be shaded with pine trees are coffee based on the advice of forest officials, besides that because it is from my father and easy to care for".

Coffee farmers in the Tawangargo area are indeed mostly coffee farmers due to Perhutani's call for soil conservation, as stated by Rasiska \& Khairullah (2017), that ecologically, coffee plantations planted in forest areas have become conservation areas for soil and water and has high biodiversity. The mushrooming trend of coffee consumption is also one of the reasons for maintaining coffee farming.

PJ "The reason I became a coffee farmer was because I passed on from my parents, my parents succeeded in growing coffee, so I just continued, besides that now many coffee shops have sprung up, of course, they need coffee".

The development of coffee consumption trends can be said to be growing, this can be seen from the increasingly mushrooming growth of coffee shops in various cities in Indonesia. The habit of brewing coffee has become a routine and even a lifestyle Hamzah et al., (2021).

\section{Local agriculture instructor}

The role of extension workers in the transfer of coffee farming activities in the Karangploso subdistrict is still very small because coffee farmers in Karangploso sub-district feel that their desire to become coffee farmers is beyond the encouragement and support of local agricultural extension workers.

$\mathrm{NH}$ "I used to want to be a coffee farmer because I like coffee, so there was no encouragement or input from agricultural extension workers at that time, the reason could also be because there was no agricultural extension for coffee commodities at that time"

MS "Look, sir, in the past, I actually became a coffee farmer because my garden belonged to my parents, and I as his son continued the garden and rice fields from my father. so it has nothing to 
Volume: 07, Issue: 05 "September-October 2021"

do with being given input or being given advice by agricultural extension workers to become coffee farmers."

PJ "Agricultural extension workers for coffee commodities have not been around for a long time, so when I first became a coffee farmer, I didn't know the name of an agricultural instructor. now it's okay for extension workers to help coffee farmers."

GT "if there is an agricultural extension agent, maybe there is no encouragement to become a coffee farmer at the beginning, but if the forest officer is there, because it is a collaboration with the forest officer."

Encouragement, education, or assistance from local agricultural extension workers is still considered new for coffee commodities so that new coffee farmers feel the existence of local extension workers for new coffee commodities in recent years. According to Nurjanah et al., (2016), there are several roles of agricultural extension workers, namely:

1. Education, is an activity to facilitate the learning process carried out by beneficiaries of extension workers and or other development stakeholders.

2. Dissemination of information/Innovation, is an activity of disseminating information/innovation from information sources or recipients of the information.

3. Facilitation/assistance, is the role of extension workers in terms of serving, meeting farmers' needs, facilitating farmer complaints or farming problems faced by farmers.

4. Consultation, which is to help solve problems or simply provide problem-solving alternatives.

5. Supervision/guidance is a supervisory activity carried out jointly between extension workers and farmers to see and know the development of the farming carried out.

6. Monitoring/evaluation is a monitoring activity carried out to ensure whether the available inputs or resources have been optimally utilized by farmers

\section{Land tenure and land area}

Land tenure includes simple ownership such as rent to the right to use the land as a means of relief and guarantees by the government or the private sector. When the number of land tenure increases, the poverty rate will decrease (Ainurrahma et al., 2018). Not all coffee plantations cultivated by coffee farmers in Karangploso District are private land, but there are some lands that do belong to forest officials but already have permits to manage the land with several 
agreements with forest officials. Most of the coffee plantations in collaboration with forest officers are located in Donowarih Village and Tawangargo Village.

GT "From the forest officer, he was told to grow coffee, so that the forest land can be more useful, after the harvest, the results will be shared with the forest officer".

PJ "There are a lot of pine trees in the forest, so the plants that can live under the shade of pine trees are coffee plants, right if there is coffee there must be shade".

Coffee farmers in Bocek and Ngenep villages, on average, coffee plantations are privately owned and continue to be coffee farmers because they are still considered promising and do not want to bother dismantling land and changing plant types, but for Donowarih Village and Tawangargo Village, most of the farmers' garden land coffee is in the forest and has cooperation with forest officials, so coffee farmers in Donowarih and Tawangargo villages cannot replace their commodity crops unilaterally because coffee plantations are in forest areas.

\section{Income from other sectors}

On average, coffee farmers in Karangploso Sub-district not only depend on coffee plantations for their livelihoods, but also on other types of commodities such as vegetables and tubers, which are still in the agricultural sector. Most of the households in the village depend for their income on the agricultural sector, most of the farmers in the village think for the convenience of getting income when they are old so they prefer to become farmers (Septiasari et al., 2013).

$\mathrm{NH}$ "In addition to growing coffee, you can also grow rice and vegetables, because coffee is an annual, and it doesn't bother you how to take care of it, so you have a lot of free time if you just rely on coffee"

MS "Coffee garden is just a sideline, bro, because it's easy and not complicated to take care of it, so there are vegetables in the fields too, not just coffee"

PJ "My coffee plantation is only an annual income, so there is also monthly income from vegetables and daily sales"

People's income in other sectors does not really affect the regeneration of coffee farmers in Karangploso District, because almost all coffee farmers make coffee farming as a side job or annual income. Coffee farmers choose to continue or develop coffee farming apart from liking and passing on from generation to generation as well because it is easy to maintain so that as they get older they don't have to worry about spending a lot of energy to work. 
International Journal of Agriculture and Environmental Research

ISSN: $2455-6939$

Volume: 07, Issue: 05 "September-October 2021"

\section{CONCLUSION}

Based on the results of the analysis and what has been described in the previous chapter, it can be concluded that:

1. The regeneration of coffee farmers in the Karangploso District occurs only in four villages namely Bocek, Ngenep, Donowarih, and Tawangargo. The regeneration of coffee farmers in the Karangploso District occurs only through the family's internal environment involvement, where the transfer of farming from parents to their children has been going on for three generations. The types of coffee that are cultivated are Robusta and Arabica. The average level of education of coffee farmers in Karangploso District is only up to elementary school.

2. The role of local agricultural instructor in the transfer of coffee farming activities in Karangploso District is still insignificant. The education level of coffee farmers in the Karangploso district is still very low, with the majority only reaching elementary school (ED) and only a few reaching junior high school (JHS). Not all coffee plantation land owned by coffee farmers in Karangploso District is private property, but in Donowarih Village and Tawangargo Village, most of the area are a result of collaboration with forest officials. Coffee farmers in Karangploso district did not fully depend on their income from coffee farming, but also from other commodities within the the agricultural sector. The strong reason for growing coffee is not only because it is passed on from generation to generation, or because they are bothered to change commodities, but because of the ease in maintenance of the coffee plant which is considered suitable by farmers from old age.

\section{REFERENCES}

[1] Ainurrahma, A., Nuryartono, N., \& Pasaribu, S. (2018). Analisis kesejahteraan petani: pola penguasaan lahan di Kabupaten Lamongan. Jurnal Ekonomi Dan Kebijakan Pembangunan, 7(2), 102-117. https://doi.org/10.29244/jekp.7.2.102-117

[2] Anwarudin, O., Sumardjo, Satria, A., \& Fatchiya, A. (2020). Proses dan pendekatan regenerasi petani melalui multistrategi di Indonesia. Jurnal Penelitian Dan Pengembangan Pertanian, 39(2),

https://doi.org/http://dx.doi.org/10.21082/jp3.v39n2.2020.p73-85

[3] Hamyana. (2017). Motif kerja generasi muda di bidang pertanian: studi fenomenologi tentang motif kerja di bidang pertanian pada kelompok pemuda tani di Kota Batu. Mediapsi, 03(1), 34-42. https://doi.org/10.21776/ub.mps.2017.003.01.5

[4] Hamzah, M. S., Baroh, I., \& Harpowo. (2021). Analisis pemasaran biji kopi robusta di Desa Jambuwer Kecamatan Kromengan Kabupaten Malang. JJurnal Agriecobis (Journal 
International Journal of Agriculture and Environmental Research

ISSN: 2455-6939

Volume: 07, Issue: 05 "September-October 2021"

of Agricultural Socioeconomics and Business), 4(2), 65-74. https://doi.org/10.22219/agriecobis.v4i1.15824

[5] Ibrahim J., T., Mazwan M., Z. (2021) Structural Transformation of Agricultural Sector in East Java Indonesia. SSRG International Journal of Economics and Management Studies. Volume 7 Issue 3, March 2020. ISSN: 2393-9125

[6] Ibrahim J., T., Mazwan M., Z., Mufhriantie F. (2021) Factors Affecting Rural Youth Interest in Agriculture in Probolinggo District Indonesia. International Journal of Humanities Social Sciences and Education. Volume 8, Issue 1, January 2021, PP. 59-66. doi:10.20431/2349-0381.0801008

[7] Ibrahim, JT., Mufriantie, F. 2021. Sumberdaya Manusia Sektor Pertanian Dalam Berbagai Perspektif. Psychology Forum. Indonesia.

[8] Juliansyah, H., \& Riyono, A. (2018). Pengaruh produksi, luas lahan dan tingkat pendidikan terhadap pendapatan petani karet di Desa Bukit Hagu Kecamatan Lhoksukon

Kabupaten Aceh Utara. Jurnal Ekonomi Pertanian Unimal, 1(2), 65-72. http://ojs.unimal.ac.id/index.php/JEPU

[9] Mishra, A. K., El-Osta, H. S., \& Shaik, S. (2010). Succession decisions in U.S. family farm businesses. Journal of Agricultural and Resource Economics, 35(1), 133-152. https://doi.org/10.22004/ag.econ.61055

[10] Nasution, S. (2011). Metode Research : Penelitian Ilmiah. Bumi Aksara.

[11] Nurjanah, Cepriadi, \& Kausar. (2016). Peran penyuluh pertanian dalam pengembangan kelompoktani di Desa Kemuning Muda Kecamatan Bungaraya Kabupaten Siak. Jom Faperta, 3(2), 1-14.

[12] Rahmawati T., E., Ibrahim J., T., Relawati, R. (2021) The Perception of Women Migrant Workers on Agricultural Work in Tanggulturus Village, Besuki District, Tulungagung Regency. SSRG International Journal of Agricultural and Environment Science. Volume 8, Issue 3, 23-27, May-June 2021. ISSN: 2394-2568/doi:10.14445/23942568/IJAESV813P104.

[13] Rasiska, S., \& Khairullah, A. (2017). Efek tiga jenis pohon penaung terhadap keragaman serangga pada pertanaman kopi di Perkebunan Rakyat Manglayang, Kecamatan Cilengkrang, Kabupaten Bandung. Jurnal Agrikultura, 28(3), 161-166. https://doi.org/10.24198/agrikultura.v28i3.15750

[14] Septiasari, M. I., Diarta, I. K. S., \& Dewi, R. K. (2013). Perbandingan antara pendapatan rumah tangga petani di Subak daerah pariwisata dan non pariwisata. E-Jurnal Agribisnis Dan Agrowisata, 2(4), 236-246.

[15] Wardani, \& Anwarudin, O. (2018). Peran penyuluh terhadap penguatan kelompok tani dan regenerasi petani di Kabupaten Bogor Jawa Barat. Jurnal TABARO, 2(1), 191-200. 